University of Minnesota Morris Digital Well

University of Minnesota Morris Digital Well

6-8-2016

\title{
"Our Girls Have Grown Up in the Family": Educating German and Chinese Girls in the Nineteenth Century
}

\author{
Fang Qin \\ Capital Normal University \\ Emily Bruce \\ University of Minnesota - Morris, bruce088@umn.edu
}

Follow this and additional works at: https://digitalcommons.morris.umn.edu/history

Part of the Asian History Commons, Cultural History Commons, and the European History Commons

\section{Recommended Citation}

Qin Fang and Emily Bruce. "'Our Girls Have Grown Up in the Family': Educating German and Chinese Girls in the Nineteenth Century." Journal of Modern Chinese History 10, no. 1 (2016): 1-18.

This Article is brought to you for free and open access by the Faculty and Staff Scholarship at University of Minnesota Morris Digital Well. It has been accepted for inclusion in History Publications by an authorized administrator of University of Minnesota Morris Digital Well. For more information, please contact skulann@morris.umn.edu. 


\title{
"Our Girls Have Grown Up in the Family": Educating German and Chinese Girls in the Nineteenth Century
}

\author{
QIN Fang (fqin@cnu.edu.cn) \\ College of History, Capital Normal University, Beijing \\ Emily BRUCE (bruce088@umn.edu) \\ Department of History, University of Minnesota-Morris, Morris
}

In this article, we examine and compare historical changes in girls' home-based education in nineteenth-century Germany and China. In many ways, girls' homebased education in these two historical contexts exhibited differences, including the relationship between formal schooling and home education, and the role that new genres played in shifting tradition and structuring girlhood. However, we argue that more commonalities between the German and Chinese cases emerge. By analyzing the relation between talent and virtue, the writing of exemplary lives, and family dynamics, we see that in both cases the home was the critical site for valorizing and reproducing the class-bounded ideology of domesticity and identification for girls as home-based education constituted the means by which knowledge, morality, and practical skills were produced and transmitted from generation to generation.

Keywords: girls' home-based education; German; China; ideology of domesticity; class

\section{Introduction}

Our title is adapted from a ninth-century poem written by the famous Tang poet Bai Juyi (772-846). This line captures something essential about the education of young women in both historical contexts we are comparing: the intimate family served as the primary site of girls' informal learning in both German and Chinese households. In this article, we expand historical understanding of changes in girls' education around the globe in two significant respects: first, by investigating the complex and understudied sphere of informal home instruction over the long 
nineteenth century; and second, by approaching questions about the history of girlhood comparatively, with evidence from German and Chinese families. ${ }^{1}$

In many aspects, girls' education looked quite different in these two contexts. For girls across Europe, the nineteenth century was a time of radical change with the spread of compulsory mass schooling. ${ }^{2}$ China seemingly presents a stark contrast: until the emergence of formal schooling in the second half of the nineteenth century, young Chinese girls received almost all of their education at home. Similarly, most of the practices in girls' home-based education in China were long inherited from their predecessors, tying these young girls closely to women's tradition. Meanwhile in the German case, although some practices were longstanding, important new genres, such as diary writing and youth literature, began to emerge in the eighteenth century as literacy spread.

However, we argue that by incorporating the still-understudied component of informal education that girls received at home in addition to or instead of school, more commonalities between the German and Chinese cases emerge. In both cases, the home was the critical site for valorizing and reproducing the ideology of domesticity for girls as home-based education constituted the means by which knowledge, morality, and practical skills were produced and transmitted from generation to generation. In central Europe, the drive to secure prosperity for an emerging middle class through education produced tensions and contradictions around the value and threat of literacy, the cultivation of natural behavior, and the gendered boundaries of knowledge and virtue. In China, girls fueled themselves through home-based education with Confucian womanly virtues, appropriate literary talents, and/or inherited familial tradition to prepare for their future marriage-oriented roles. Pedagogues and parents in both places attempted to cultivate appropriate girlhood by canonizing exemplary figures in such genres as official histories, pedagogical texts, and family stories. Meanwhile, home-based education also

\footnotetext{
1 In both settings, we consider "girl" as a category that spanned a broad age range from childhood to young adulthood.

2 Edicts promising state-sponsored primary schools for all girls and boys below age 12 or 14 first appeared in the late eighteenth century (as early as 1763 in the case of Prussia). However, the actual enforcement of these laws was spotty at best, particularly for girls.
} 
became a key way in which girls interacted with family members and thus fostered a sense of class-bounded belonging and identification.

Perhaps the primary reason the role of girls' informal education in both Chinese and German history has been neglected is a problem of evidence. Yet partial documentation of educational practices created by young women themselves is available in both cases. Our approach brings together sources from both ideological perspectives: pedagogic texts and official histories that reveal prescriptive visions for girls' education, and records of experience such as personal narratives, letters, journals, and poetry that present individual girls' and families' educational practices. We argue that the genres chosen for and by young women to facilitate their education at home were not coincidental, but rather manifest central nineteenth-century ideological ideas about gender, social status, and education. By placing these cases alongside one another, we are in the process of accumulating knowledge about various educational practices in these two places during the modern era, as well as developing methods that give us purchase on deeper comparative questions.

\section{Educating girls at home}

\section{The German Case}

The most salient difference between China and central Europe in the education of girls during the nineteenth century was certainly formal schooling. Secondary schooling for girls in Europe typically included lessons in domesticity, although the definition of those skills varied regionally; the most elite levels of secondary schools, such as the German gymnasium, were usually restricted to boys. ${ }^{3}$ Girls' education was also generally religious, but again, regional (and confessional) differences played out in different ways; the religious nature of girls' schooling was also increasingly contested in the late nineteenth century. Feminist campaigns began to play a role on the international stage in calls to strengthen girls' secondary schools starting in the 1860s and 1870s. In the German case, the percentage of girls receiving a formal education was indisputably on the rise. For example, in Prussia, the presence of between 250 and 350 public

\footnotetext{
3 Albisetti, Goodman, and Rogers, Girls'Secondary Education in the Western World.
} 
girls' schools during the period from 1827 to 1864 ensured a secondary school for girls in every large town. ${ }^{4}$ But whether a girl was educated at school or not (and most continued not to be, even in the middle and upper classes), informal instruction at home was always a critical component of German girls' education, as it was in China. This section of the paper uses four pedagogic genres to explore the purposes of educating German girls at home and the content of that education, with special focus on the gendered virtues emphasized by pedagogues.

This paper examines two genres as representative of pedagogic texts consumed by German girls: the new youth periodicals (which emerged at the end of the eighteenth century) and schoolbooks (geography and world history). Girls certainly read books marketed for their brothers and male classmates, as girls have long done. But texts produced specifically for girls afford a special opportunity to see explicit ways in which learners' reading experiences were gendered. Authors of periodicals - which contained a variety of illustrations, sheet music, poetry, riddles, games, essays, and dramas-emphasized pleasure in this proto-children's literature because they were increasingly concerned about how to capture young people's attention for intellectual and moral instruction. As for geographic texts, these were produced either for the small but growing number of girls' secondary schools or for instruction at home with parent or tutor supervision.

For texts produced by girls, this paper focuses on letter and diary writing. Letter writing connected bourgeois girls in networks with traveling parents, distant friends, or their brothers away at school. Girls were taught how to write letters through rhetorical manuals and adult supervision. Meanwhile, diary writing was the quintessential genre for educated European girls in the nineteenth century, used to cultivate adult subjectivities through scrutiny of the self. While older girls appear to have written primarily for themselves, younger writers expected an immediate audience for their diaries in the form of a tutor or parents. Such documents thus reveal not only an awareness of readers and genre, but also the quotidian workings of girls'

\footnotetext{
4 Jacobi, "Girls' Secondary Education," 10. German literacy rates were also quite high compared to the rest of Europe: by 1850, 85 percent of Prussia's population could read and write, compared with 52 percent in England and 61 percent reading literacy in France. Barkin, "Social Control and the Volksschule," 50. Female illiteracy is estimated to have declined to under 10 percent by the mid-nineteenth century, if not earlier. Vincent, Rise of Mass Literacy, 9.
} 
domestic, intellectual, and moral education.

Across these genres, three purposes for educating girls in central Europe are evident. First, the education of girls and women was increasingly understood as essential to securing middleclass power and prosperity. This included but went beyond training girls as the first educators of the next generation. The pedagogue J. G. Reinhardt, for example, presented catastrophic consequences of being an uneducated woman in his periodical The Girl's Mirror. In "On the Use of Reading and Writing," a dishonest man discovered that Anastasia, who had inherited some money, could neither read nor write. Drawing up a fraudulent loan agreement, he disappeared with her money. The story ended with Anastasia's sad reaction: “'Oh, if only I had learned to read and write!' And from that time she told all children to go to school diligently, where they could learn to read and write." ${ }^{5}$ One might accuse Reinhardt of preaching to the converted here, extolling the virtues of literacy via the written word. But this melodramatic example is also interesting because it suggests that young women should have control over their money and the education to manage it.

Second, partly as a means of promoting middle-class power, girls' education in the domestic context sought to cultivate bourgeois sociability, which could be taught through letter writing and other practices. As a teaching form, letters were used by children to practice a number of different skills and demonstrate their knowledge of topics from political geography to religious doctrine. But by far the most common pedagogic purpose of letter writing was the development of young people's social literacy, their capacity to "read" their social world and navigate family and business relationships. For example, 11-year-old Bettina Brentano filled an entire letter to her sister Kunigunde with explanations of why she could not write her a letter:

You asked me all sorts of [questions] in your letter, but I cannot answer all of them, partly because the post is going out soon, and also because I have lost the letter, and I do not have any more time left to look for it....Only this news can I tell you, that Marie Sophie [another sister] is angry with you because you have still not written to her. ${ }^{6}$

Letters like this exerted a social as well as a pedagogic purpose, even without reporting much

\footnotetext{
5 Reinhardt, Der Mädchenspiegel, 74.

6 Bettina Brentano to Kunigunde Brentano, dated September 7, 1796, in F. E. Mencken, Dein dich zärtlich liebender Sohn [Your Affectionate Loving Son], 101.
} 
news. Brentano used correspondence to negotiate relationships with these two sisters and others whether or not she had specific information to communicate.

Diaries also record girls' developing sociability both within and beyond the family. Bourgeois girls in the nineteenth century increasingly relied on writing as a tool in the development of their social relationships, as when seventeen-year-old Anna Hasenfratz noted in her diary in 1841 that she had made a gift of a few lines and her signature as a souvenir for a friend's autograph book. ${ }^{7}$

A third purpose of informal education was the more straightforward development of girls' skills and knowledge. Geographic schoolbooks usefully reveal ambivalence among German educators about how specialized women's knowledge should be. Just as more and more girls were pursuing an education that included situating them in a global market and culture, practical exploration of that world was denied to them and gender-specialized texts for children proliferated. Certain virtues - notably, self-control and obedience-were celebrated more in female youth, while boys began to read more tales of heroism and cleverness. ${ }^{8}$ And yet textbook author Friedrich Nösselt used the very gender ideologies emerging from the Enlightenment, which excluded women from active public participation in the world, to argue in the early nineteenth century that the education of girls in geography and world events was important. By teaching girls about the past and the nature of other nations in the world, he hoped to impress upon them the importance of "an excellent paternal world order." ${ }^{9}$ And yet at times, he seemed to equivocate about what his female audience required that was different from boys' education: he suggested that teachers of girls should emphasize "the beauty of magnanimity and the damnability of vice and weakness," but he also allowed that "much of what boys learn, girls must also know." 10

In order to achieve these aims, girls' informal education covered a range of skills, including literacy, domestic tasks, and household management. But through and in support of instruction in these concrete skills, girls' education also emphasized the cultivation of a specific set of virtues,

\footnotetext{
7 Anna Hasenfratz, Diary, entry dated June 13, 1841.

8 Barth, "Das Goldtöchterchen," 61-75.

9 Nösselt, Lehrbuch der Weltgeschichte für Töchterschulen, iv.

10 Ibid., iv.
} 
especially industry, discipline, sensibility, and literacy. At the same time, pedagogic texts warned against the dangers of feminine curiosity, vanity, or worldliness.

The central virtue of middle-class girlhood in nineteenth-century German families was industry. In 10-year-old Marie Seybold's short entries of the 1830s, clearly kept with an adult audience in mind, her regular observations on her own industriousness often constituted an entire day's record. Interestingly, these comments were usually positive- "Today I was diligent" and there were few reports of days when she or someone else found her work lacking. One mysterious variation came on May 26, when she observed, "Nothing else happened that deserved to be remarked on, other than that I have been diligent."11 In a different hand, the last line, "that I have been diligent," was later underlined and an exclamation point added at the end. Was the adult reader contradicting Marie's self-assessment? Or confirming and commending her hard work? Without any other clues, it is still worth observing that both Marie and the readers of her diary understood writing as a means to engage in this kind of self-review and that industry versus idleness was the key axis of self-improvement.

While diligence was a critical virtue for girls and boys alike, other qualities that informal education sought to cultivate were more explicitly targeted at daughters. Pedagogues and parents promoted a gendered philanthropic selfhood, deeply implicating girls in the making of class cultures. One example can be seen in the report "The Charity of Some Young Girls," from an 1806 issue of the youth newspaper Bildungsblätter. The story told of two girls aged eight and nine who heard about poverty in Saxony and decided to save their pocket money to purchase material for winter clothes, which they sewed themselves for the poor children. Whether the tale is read as advocacy of compassionate giving or a self-congratulatory middle-class fantasy, what is especially interesting here is the link the author made between literacy and moral development. The piece opened with the question, "What good child would not gladly hear or read something about such young people, who are invigorated by this beautiful spirit of good deeds?"12 And it closed by underscoring the same sentiment, suggesting that reading about these girls might encourage

\footnotetext{
11 Marie Seybold, Diary, entry dated May 26, 1830.

12 Johannes Christian Dolz, "Wohlthätigkeit einiger jungen Mädchen" [The Charity of Some Young Girls] in Bildungsblätter oder Zeitung für die Jugend [Picture Pages, or A Magazine for Youth] (Leipzig: Georg Voß, 1806), 296.
} 
other children to make sacrifices for the pleasure of charity. The individual most pedagogues wanted to cultivate in a girl was a compassionate, devoted, selfless person directed toward serving others. Both boys and girls were taught to be sensitive and devoted to their families, but the ideal female vocation required disregarding individual personalities and desires - the selfless self.

Another virtue emphasized in the domestic education of German girls was the quality of being "natural," which was ambiguously and even paradoxically defined. Sixteen-year-old Anna Krahmer, for example, recorded the following novelistic exchange with her brother in her diary:

Gustav: You are not at all natural, Anna.

I: I am natural, but my nature is contorted and refined and polished, that is a necessity. I am always natural, but that nature is miserably impaired, more's the pity. I am pathetic.

He: Yes, why are you so? Earlier you were better, that is true.

I: You say that; you liked my coarse, boisterous, open, honest character much better, when I said what I thought and did what I wanted!

The contrast of nature and cultivated refinement echoed fundamental concerns about girls' education, demonstrating the contradictions of cultivating naturalness and the gendered tensions of that ideal. Anna also reflected on the malleability of her own character, consenting to general notions of virtue and moral improvement but still resisting the controlling judgment of her meddlesome young relatives. ${ }^{13}$ By recording her perspective on the conversation and relationships, she inscribed a self in her diary.

\section{The Chinese Case}

Compared with Europe, women's schooling was a belated project in China. In 1842, in Ningpo, one of the first five treaty ports open to Western imperialists, a female missionary established the first girls' school, mainly enrolling young girls from poor families for the purpose of evangelism. ${ }^{14}$ Half a century later in 1898, as part of the agenda for modernity-oriented reformation and nationalism, the first Chinese-managed girls' school was established in Shanghai,

\footnotetext{
13 Anna Krahmer, Diary, entry dated September 25, 1831.

${ }^{14}$ For a brief history of missionary-run girls' schools in China, see Du Xueyuan, Zhongguo nüzi jiaoyu tongshi, 250-254.
} 
then the most prosperous city in China, taking girls from genteel families. Concerned about departing too far from orthodox Confucianism and thus eliciting criticism, the school curriculum was still a hybrid of traditional Chinese knowledge and modern Western subjects. ${ }^{15}$ It is thus safe to conclude that before the second half of the nineteenth century, almost all girls, especially those from elite families, were educated at home if at all. This section first draws a generalized picture of Chinese girls' home-based education and then elaborates that through a case study of one family's education of four daughters in the second half of the nineteenth century.

Not dissimilar to the situation in Europe, the home-based education of Chinese girls usually consisted of three parts: basic reading and writing literacy; practical household management skills like cooking, weaving, and embroidery; and the inculcation of Confucian womanly virtues and sometimes domestic religion. ${ }^{16}$ Some genteel families who had sufficient resources and especially cherished their daughters probably also cultivated advanced literary skills including poetry, painting, or calligraphy in girls' early years. Writing a poem or painting a painting was not only an exhibition of respectable womanhood, it was also located within a rich tradition of women's culture. ${ }^{17}$ Those with outstanding literary achievements were usually crowned with the title of "talented woman," probably the most valorized metonymical figure of Chinese women's culture before the second half of the nineteenth century. ${ }^{18}$ Poetry, as women's most favored literary genre of self-representation for centuries, provides the main source for looking into Chinese girlhood and home-based education. Interestingly, since many women produced poems prolifically after they married or became mothers, the pieces that touched upon their girlhood years were composed in a very nostalgic tone in the contrast to "women's loneliness, isolation, and emotional privation in marriage."19 Their portrayal of the years in which they grew up was thus tinged with pleasant memories of family members.

One of the most influential Confucian ideologies regarding Chinese women was gender

\footnotetext{
15 Xia Xiaohong, "Zhongxi hebi de jiaoyu lixiang," 3-37; Bailey, Gender and Education in China, 15-25.

16 Mann, "Education of Daughters," 19-47; Ho, "Cultivation of Female Talent," 196; Cong Xiaoping, "Cong muqin dao guomin jiaoshi," 88.

17 For a history of women's culture in the seventeenth and eighteenth centuries, see Ko, Teachers of the Inner Chambers, and Mann, Precious Records.

18 At the end of the nineteenth century, the image of the talented woman and her poetry writing was criticized for its incompatibility with modern national agendas. Hu, “Naming the First New Woman," 196-231.

19 Mann, Precious Records, 13.
} 
separation, or the so-called nei/wai (inner/outer) boundary. Women, regardless of their social status, were expected to stay within the inner chambers of the household and not to go outside unescorted. Men, instead, could leave home to travel, to socialize with friends and relatives, to attend civil service examinations, or to do business. The gender separation was intended to prescribe appropriate roles for both sexes in their adult years. However, for girls and boys under a certain age, there was some flexibility in this principle. Until the age of seven, and sometimes ten, in some genteel families, girls and boys were allowed to study together with no specific gender difference. ${ }^{20}$ The textbooks included Sanzi jing (Three-character classic) and Qianzi wen (One-thousand-character classic), the most basic primers for the education of children of both sexes since the sixteenth century. ${ }^{21}$ It took a child about two years to finish the primers and master about two thousand Chinese characters.

Apart from literary training, womanly virtues also became a subject of didactic literature to instruct girls in daily living. This included texts like Chen Hongmou's Jiaonü yigui (Bequeathed instructions for the education of girls), which was reprinted at least twice in the second half of the eighteenth century, and many others. ${ }^{22}$ Pamphlets like Chen's usually listed all the principles and expectations that girls and women should abide by down to the very last detail. In terms of the role of daughters, they outlined the appropriate time, dress, behavior, and deportment for the interaction of a daughter of a genteel family with her parents.

In most families, parents played a vital role in guiding the formation of girls' knowledge, but sometimes relatives like grandparents, aunts, uncles, and even senior siblings substituted for absent parents. Some families even retained a governess to stay for years to intensively instruct the daughters at home. In regard to studying, parents tended to be more lenient to daughters than to sons. This was because girls were not obligated to perpetuate the family's reputation by taking the civil service examination and pursuing officialdom, and in fact, would probably marry into a totally strange family when they grew up. ${ }^{23}$

\footnotetext{
${ }^{20}$ Generally speaking, it was quite common in the late imperial period for boys and girls under the age of seven or ten to study together. Hsiung, Tender Voyage, 205-207.

${ }^{21}$ For analysis of these two primers, see Wu, "Education of Children in the Sung," 322-324.

22 Mann, Precious Records, 28-29.

23 Hsiung, Tender Voyage, 199-202.
} 
However, after the dividing age (seven to ten), boys and girls were separated for different subjects and purposes. Boys were usually taught to compose patterned essays and poetry to prepare for their adulthood, in which they, by cultivating proper civil capacity, either took the civil service examinations or socialized with other elite peers to form their own network. In contrast, girls usually retreated from the study to the inner spaces of boudoirs or kitchens and prepared themselves for future married life. ${ }^{24}$

The case of the four sisters in the Lü family can provide further detail about girls' homebased education in the second half of the nineteenth century. Huiru (1875-1925), Meisun (18811945), Bicheng (1883-1943), and Kunxiu (1888-1942), were the four daughters of Lü Fengqi (18371895) and Yan Shiyu of Anhui Province. ${ }^{25}$ Like most elite families in late imperial China, the homebased education of the Lü family was greatly shaped by the father's political pursuit of civil service examinations and then officialdom. Lü Fengqi devoted the majority of his time and energy to the civil service and participated very little in the education of his daughters. Most of their early education was thus carried out by their mother and her maternal family. For example, in 1885, when the eldest daughter was ten, the second daughter was four, and the third daughter was two, the mother, Yan Shiyu, brought the three daughters from the father's post in Shanxi to Beijing and lived with her maternal family. It was not common for daughters with three children to move back with the maternal family. But probably the fact that the father was then the Educational Commissioner of Shanxi Province played a critical role in this situation, as he capably provided material and political resources for his immediate and extended families. But in the minds of the little girls, none of these complicated considerations existed; they had lovely memories of living in the compound with three generations of the Yan family. From the second daughter Meisun's poetry and essays, we can see that not only did the grandmother demonstrate her fondness by providing them with embroidered dresses and delicious snacks, ${ }^{26}$ more importantly, the two elder girls were able to join their cousins in receiving elementary education at the Yan family

\footnotetext{
24 For a general introduction to the life trajectories of both sexes, see Mann, Precious Records, 47-75.

25 For a more detailed analysis of the education of the Lü sisters, see Qin Fang, "Wanqing cainü de chengzhang licheng."

${ }^{26}$ Lü Meisun, "Chong zhi jingshi," 5.
} 
school. ${ }^{27}$ The existence of the school indicated that the Yan family was capable of and willing to invest money and resources in children's education, and it shows that it was permissible for boys and girls up until around the age of ten to study together with no specific gender difference. Both boys and girls at the Yan family school studied Sanzi jing and Qianzi wen, as did most children in imperial China. Within two years of their arrival in the Yan compound, Meisun completed the primers with fluency sufficient to outsmart one Yan cousin and to win the favor of the tutor. ${ }^{28}$ As for Huiru, the eldest, she had already composed ten poems at the age of twelve. ${ }^{29}$ This indicated at least that she was trained in rhythmics and poetry writing.

In 1887, Lü Fengqi resigned from his position and brought his wife, three daughters, and two sons back to Lu'an, where they new compound was located in Anhui province. The youngest daughter was born soon, but unfortunately the new birth was followed by the death of the two sons. With no surviving male heir, the parents had no outlet for their sorrow except supervising the education of their daughters. ${ }^{30}$ The first two daughters were already well educated at the Yan family school. Accordingly, their father hired a Lü clan member to teach the girls at home and then hired another tutor specially to teach the girls painting. In about four or five years, the eldest daughter's painting skills improved to the point that "the father's sorrow was slightly relieved."31 Bicheng, the third daughter, was also able to rhythemize, or compose poetry, beautifully with the father. According to one anecdote, one day when she was in the garden with her father, he composed the line "the spring wind blowing the willow" upon seeing the willow tree in the garden. Immediately Bicheng, who was standing next to her father, rhythmized with the line "the autumn rain striking the wutong tree." ${ }^{32}$ Bicheng's five-character line shows she was already capable of using the verb "strike" to describe the relationship between two objects in nature, the autumn rain and the wutong tree, in response to her father's line.

Meanwhile, when Meisun was 11 or 12 years old, she was taught to write rudimentary essays and poems that were originally designed for the men's civil service examination. She so

\footnotetext{
27 Lü Meisun, "Meisun ziji sansheng yinguo," 84.

28 Lü Meisun, "Chong zhi Jingshi," 5.

29 Lü Fengqi, Shizhushannong xingnian lu, 410.

30 Ibid., 410.

31 Ibid., 411.

32 Guang Tiefu, Anhui mingyuan shici zhenglüe, 21.
} 
excelled that "both father and the tutor appreciated my work." ${ }^{33}$ Allowing a daughter to study the subjects of the civil service examination was probably the result of the father's "compensation" mentality: at a general level, daughters were not expected to carry on the family reputation by advancing in the civil service, and at a more specific level, in the Lü family, there was no son. But the curriculum indeed went far beyond what a girl of the inner chamber was supposed to study.

In retrospect, it was their home learning that helped these young women survive the family crisis after their father's sudden death in 1895. The death of their father marked the collapse of the family's material shelter and the dramatic end of the daughters' girlhood. In the following years, all four daughters, married or not, engaged with modern women's education in one way or another and became pioneers in this progressive cause. Unlike their predecessors who usually had no choice after a crisis but to make a living through womanly work at home, ${ }^{34}$ the Lu daughters were able and willing to support the family by trading their home learning for economic security, self-fulfillment, and social recognition.

\section{Towards a Comparative History of Girls' Education}

In this initial phase of our comparative project, we trace three aspects of girls' homebased education in the nineteenth century that resonate between the German and Chinese cases: tension between talent and virtue as primary goals in the instruction of girls at home; the use of exemplary models in educating girls; and the differentiated roles of parents in learning.

\section{Talent and Virtue: Attitudes towards Girls' Instruction at Home}

The relationship between talent and virtue played a critical role in shaping the ideology of girls' education in both contexts. In the German case, bourgeois accomplishments and even intellectual development were not necessarily incompatible with virtue; indeed, girls could demonstrate their industry and self-discipline through academic performance in home-based education or at school. But what the comparison with China casts in relief is the limits to that tenuous alliance between talent and virtue. German pedagogues also believed there were

\footnotetext{
33 Lü Meisun, "Meisun ziji sansheng yinguo," 85.

34 Fong, "Female Hands," 8.
} 
dangers to educating girls, including the threat of unbridled feminine curiosity. Some authors of periodicals justified their publications as a defense against the temptations of novel reading, both popular and pernicious for girls. For example, the pedagogue J.T. Hermes wrote, "One would always like to give good novels to young girls, but unfortunately! Where are the good ones? I have never seen any." 35 Anna Hasenfratz recorded in her diary her elation at receiving permission from her older brother to read novels after she solicited his approval: "He also gave me a brief answer to my question. He wrote: 'If only the novels do not turn your head, then it is quite alright!!!' I am entirely beside myself about this message." ${ }^{36}$ Karl Engelhardt used his periodical, The New Children's Friend, to warn against the dissipations of too much dancing. He encouraged girls to learn enough for social intercourse (and even included dance patterns and sheet music in his publication), but wrote disapprovingly of how "many a young girl has trilled dance melodies all day, lived and moved in English dances and waltzes, found pleasure nowhere except at the ball, and become a passionate dancer." 37 German girls encountered countless contradictory messages like this throughout their education. As access broadened in some ways over the course of the century with the rise of mass schooling, in other ways gender norms about education were reified and the subjects or aims of educating girls were limited in the later nineteenth century.

In China, "a woman without talent is virtuous" was probably the most influential ideology shaping attitudes about girls' education, despite the fact that this exact notion did not come into being until the end of the Ming dynasty (1368-1644). ${ }^{38}$ In the long tradition of women's culture, women's virtues were usually placed above women's talents. However, since the Song dynasty (960-1279), as the civil service examination became extremely competitive, the need to educate boys became urgent. Accordingly, girls, who were expected to become future mothers, gradually received an advanced education in order to fully prepare for their future mother-tutor roles. The emergence of a large number of talented women in the Jiangnan region in the late seventeenth century could be seen as a consequence of this ideological transition. ${ }^{39}$ Genteel families began

\footnotetext{
35 Hermes, Sophiens Reise von Memel nach Sachsen, 132.

36 Anna Hasenfratz, Diary, entry dated January 1, 1841.

37 Engelhardt, Neuer Kinderfreund, issue 10 (1797), 240.

38 Chang Kang-I Sun, “Nüzi wucai bianshi de?” 268-291; Liu Lijuan, “Nüzi wucai bianshide kaoshu,” 55-60.

39 Ko, Teachers of the Inner Chambers.
} 
to take girls' learning seriously, so that in the eighteenth century, literati no longer debated whether girls should be educated but rather what girls should learn and for what purpose. ${ }^{40}$ Towards the end of the nineteenth century, with the encroachment of Western imperialism and the penetration of the nationalist agenda, the talented woman of China was gradually disparaged in public discourse since she and her literary capacity were considered a metonym for the past and tradition, things that progressive intellectuals were eager to blame in order to justify their modernity project. ${ }^{41}$

\section{Reading Exemplary Lives}

We consider the genres examined here and others that supported the instruction of girls at home as historically constitutive choices rather than simple reflections of reality. In both cases, the "exemplary lives" paradigm was popular for cultivating certain virtues in girls, especially through texts. In German education, the dissemination of exemplary lives was facilitated by a dramatic increase in book production and literacy across the nineteenth century. Reading was understood as a powerful device in the dissemination of evolving gender ideologies. As was also true in China, portraits of exemplary lives constituted one of the most common strategies to promote virtues of industry, selflessness, and naturalness in books written for girls. As Natalie Zemon Davis has written, accounts of "women worthies" are the oldest form of women's history in the Western tradition. ${ }^{42}$ "True histories" of remarkable women from the past, such as political leaders and religious figures, largely appeared in textbooks and biographical galleries. Commonly appearing figures included Helen of Troy, Dido the Queen of Carthage, the Virgin Mary, Joan of Arc, Queen Elizabeth I, Catherine the Great, and Empress Maria Theresa. The textbook author Friedrich Nösselt, for instance, highlighted the importance of St. Hedwig's influence in Germanizing Silesia, despite the fact that religious women were are not usually associated with the heroic individual lionized by Enlightenment liberalism. ${ }^{43}$

\footnotetext{
40 Mann, "Learned Women in the Eighteenth Century," 27-46.

$41 \mathrm{Hu}$, "Naming the First New Woman."

42 Plutarch is especially relevant here. Pomata, "History, Particular and Universal," 12; Davis, "'Women's History' in Transition," 83-103.

43 Nösselt, Lehrbuch der Weltgeschichte, 165.
} 
In periodicals, the individual women whose biographies were held up as models were usually fictional characters not so distant from the readers whose merits or flaws were presented as ideal or cautionary. The story “A Little Girl Shows Great Courage" from a 1779 volume of the New Year's Gift for Children magazine demonstrates this type, in which "a little sailor girl" rescues twenty people from a sinking ship. ${ }^{44}$ At the same time that her heroic action was signaled as extraordinary, the newspaper-style reporting on this anonymous girl also marked her as an ordinary person with whom the active reader should form a relationship. With amusementoriented publishing for children steadily on the rise, the model of fictional biographies found in these periodicals came to represent the primary way children read about exemplary women by the middle of the nineteenth century. Furthermore, in textbook publishing over the course of this period, though ancient and medieval heroines such as Dido or Joan of Arc were still included, biographies of contemporary female figures, for example, from the French Revolution, did not appear. Heroic women were gradually relegated to the distant past.

In China, similarly, many recognized exemplary models were usually recorded in two types of genres, local gazettes and dynastic histories, to demonstrate the integrity of local societies and the legitimacy of political regimes. In them, women were represented by their virtuous behaviors, ranging from committing suicide after a husband's death, to sacrificing for in-laws, to dying in the course of opposition to robbery or invasion of alien troops. The number of women's suicides or defensive deaths increased especially during a dynastic transition when an old regime was replaced by a new one. In the eyes of the literati who controlled women's access to and constructed their images in official history, these women's deaths mattered not only at a personal or familial level, but also at a dynastic level, as they demonstrated uninterrupted loyalty to family and to the overthrown regime. ${ }^{45}$ Most Chinese women models were not influential figures, at least not as significant as the queens, religious leaders, or political heroines in the Western tradition. They were more typically the daughters of peasant families, or the wives of officials who guarded cities, but it is exactly this obscurity that demonstrated both the efficacy and the replicability of women's virtues. They provided a baseline for young girls in imperial China, who

44 "Ein kleines Mädchen zeigt grossen Muth" ["A Little Girl Shows Great Courage"], vol. 2 (1779), 78. 45 Yi Ruolan, Shixue yu xingbie. 
were expected in their early years to emulate these models' actions and choices, and who, by doing so, were offered the possibility of recognition in official history.

In addition to official accounts, many stories regarding women models were also recorded in family histories. These stories, on the one hand, showed the penetration of the exemplarywomen tradition in individual families, and on the other hand, also added elements to the accumulated stock images and thus enriched and consolidated this tradition. In the Lü family, Meisun, the second daughter, recounted many stories about her female relatives' virtues of filial piety, submission, and tenacity. For example, in an account of lady Yan, Meisun's maternal grandmother, Meisun was convinced that the Yan family survived the Taiping rebellion (18511864) due to lady Yan's filial piety to her mother-in-law. Lady Yan cared so much about her mother-in-law that even after the mother-in-law died, lady Yan was still worried that her motherin-law's bones would be frightened by thunder. As a consequence of this filial piety, all her sons were blessed with success in the civil service examination. ${ }^{46}$ To Meisun and her sisters, these virtues were not simply a long, abstract list advocated by official histories, but instead qualities that could, and indeed did materialize on a very personal level. Stories like these were passed from mother to daughter, or between female relatives, through daily conversations that took place in boudoirs or in kitchens, or through poetry. They became a significant way of passing on women's tradition and culture and thus constituted a critical part of girls' home-based education.

\section{The Role of Family Relations in Learning}

In both the German and Chinese contexts, the family setting of girls' education was an essential factor in that instruction: how it was conducted, for what ends it was conducted, and who conducted it. Domesticity served as a backdrop for the idealized education of girls at home. While common wisdom holds that mothers were primarily responsible for informal education at home, in both our cases, patriarchal authority still held sway in the prescriptive vision of girls' learning through male authors.

In central Europe, the valorization of domesticity was reinforced through depictions of learning and family life not only in amusement-oriented genres like periodicals, but also in

\footnotetext{
46 Lü Meisun, “Xian waiwangmu Yan taifuren,” 15.
} 
explicitly instructional genres like geographic schoolbooks. Pedagogues often presented themselves as loving fathers writing for the benefit of their own daughters who were sometimes depicted within the narratives of the periodicals themselves. For example, in the early nineteenth century, Christian Schulz adapted the explorer Mungo Park's travel narrative for young German readers by setting it in a frame narrative of a family learning geography together. Schulz's adaptation begins by describing "an affectionate father of very respectable character, [with] industrious and well-constituted children. He loved them immensely, and it was his greatest pleasure to see them in their circle [around him]."47 These fictional children-Luise, age ten, Friedrich, nine, and Wilhelm, eight-ask questions of their father while he relates the story of the Mungo Park expedition. Schulz describes how gladly the father conducted his children's education, writing, "He loved very much to take a walk on fine summer days with his family in the open fields, or into the dense forest, or in the lovely gardens. Here he introduced them to the surrounding objects, large and small." ${ }^{48}$ Schulz offered his young readers an idealistic model of how they should interact with parent educators, in which "all were allowed to interrupt their father's story with items they did not understand or about which they wanted a more detailed explanation."49 Books like this adaptation of Mungo Park's narrative would not only fill young readers' minds with knowledge but also inspire their attention and imagination, directed at father-teachers.

However cloying or unrealistic this depiction of the best of fathers and most obedient of children may seem, this text provides a striking depiction of how geographic learning is bound to familial love: "They had become so used to his affectionate handling that it became the most powerful impulse for them to make themselves-through excellent, good, moral behavior and constant hard work-ever more worthy of [their father's] love and approbation." 50 Learning, including the study of geography and faraway places, was thus located in a home organized not only around a mother's care of small children but around a patriarch's instruction.

\footnotetext{
47 Schulz, Mungo Park's Reise in Afrika für die Jugend bearbeitet, 2.

48 Ibid., 4.

49 Ibid., 8.

50 lbid., 5.
} 
In the Chinese context, if we read carefully from the experiences of the four daughters of the Lü family, it is clear that the father and the mother played different, though not mutually exclusive, roles in shaping the daughters' knowledge structure and identity formation. The extent to which the father was able to invest his energy in the daughters' learning was inversely linked to his political career. The father in general distanced himself from the family and mainly focused on his career. When he was busy preparing himself for promotion, he even stopped tutoring his own sons. With the excuse that "family affairs were extremely troublesome," the father hired a private tutor to teach the boys, and he himself moved to a temple to prepare for his clerical checkup in solitude. ${ }^{51}$ The father's preoccupation with his career led him to place the sons and daughters largely under the care of their mother and her family, as stated earlier. But the whole parent-child picture changed considerably when the father decided to retire. A distant figure who showed occasional tenderness toward his daughters during his rising career trajectory, after his retreat from officialdom, the father became a caring and attentive figure who trained the daughters in the advanced literary skills of poetry and prose writing, along with painting, and calligraphy.

In comparison with the influence of the father in structuring the daughters' learning, the mother's role was much more complicated and far-reaching in the Lü family. For example, in addition to telling stories of kinswomen to pass on womanly virtues, the mother also shaped the daughters' attitude towards animal protection and not killing. Emerging around the late sixteenth century, animal liberation and not killing became one of the most widespread practices among the literati. Women of the inner chambers also earnestly engaged in these practices as routinized elements of the domestic religion. ${ }^{52}$ According to Meisun, one day when they were young, their mother dreamed she was in a desert of the underworld, being chased by a goat and a pig. She finally escaped by promising the goat and the pig that she would never eat goat or pork. Afterwards, their mother always told her daughters, "Even though pigs and goats were not specifically killed for me, I could not eat their meat. So how could I specifically kill chickens, ducks, fish, and shrimps [to eat]?" Consequently, the idea of not killing any kind of living thing was

\footnotetext{
51 Lü Fengqi, Shizhushannong xingnian lu, 398.

52 Smith, "Liberating Animals in Ming-Qing China," 51-84.
} 
practiced within the sphere of the family. "Therefore, in my family, we stopped killing [animals] in the kitchen when there were no [special] events. Later on we continued the practice of not killing, even when there were [special] events." 53

When the daughters grew up, almost all of them became advocates of not killing, publicizing these views in the mass media and at international meetings. Bicheng, the third daughter, was the most vehement. Not only did she combine the idea of not killing with Buddhism, publishing and translating articles for and from English-language newspapers around the world, she also attended international meetings, including the 1929 International Conference on Animal Protection held in Vienna. It is no exaggeration to say that the daughters' activism could be traced back to the days when their mother exerted power over the daily life of the family. Behind the family stories and the practice of not killing was the imperceptible but deep indoctrination of the daughters by the mother about the position of the self as both a woman in relation to marriage and family and a human in relation to nature.

Thus, in both the German and Chinese cases, it is clear that mothers and fathers played important, distinct roles in educating girls. Focusing on the family setting of girls' informal education illuminates the significance of those parental contributions to learning. Delineating exactly how gender shaped parental involvement in girls' home-based education in the two different contexts, however, will require future research.

\section{Conclusion}

As we have argued, girls' informal education was a critical passage toward cultivating appropriate status-bound womanhood and femininity in both Europe and China in the nineteenth century. What they learned, where they learned, and how they passed on their knowledge to later generations are both the consequence and embodiment of making elite or middle-class cultures. Despite distinct features we have touched upon in the beginning of the paper, we have explored some essential issues that developed similarly in both the German and the Chinese contexts, including the ideology of domesticity, the cultivation of virtues through the use of literacy, and concerns over the family's role in girls' education.

\footnotetext{
53 Lü Meisun, "Paochu sha jie," 88.
} 
In beginning to analyze our geographic cases alongside one another, we have identified several promising directions for future research. For example, in both contexts, marriage usually played a critical role as the ending marker of girlhood, but the experience of that institution in central Europe and China differed in many ways. How, then, did young women's education prepare them differently for responsibilities and identities in married life? Through our focus on education at home, this ongoing project offers the potential for using memoirs to think about girlhood from a life course perspective, as women reflected on their own past intellectual, moral, and political development.

Meanwhile, we can locate China and Germany in global history and think about the ways in which some elements in girls' home-based education were produced, reproduced, and transmitted along global networks. For example, in both countries, exemplary women were used as effective role models for young girls to look up to. Some of these exemplary images such as Joan of Arc or Madame Roland originated in Europe and traveled worldwide in the nineteenth and twentieth centuries. How did the transmission of these images influence girls' home and school education when they became part of imperialist expansion within Europe and between Europe and China? To rephrase this question on a larger scale, as women's education became a global phenomenon in the modern era, how did colonial fantasies and worldviews affect girls' learning in particular? Especially in China, since the emergence of women's schooling was largely a response to imperialism-inflected nationalism, what was the relationship between "home" and "school" in the physical as well as the metaphorical sense? Our paper ends with these questions, but our research does not.

\section{Notes on contributors}

QIN Fang is an assistant professor at the College of History, Capital Normal University, Beijing. She is interested in women's education and urban history in late imperial China. Her publications include "A New Word, a New World: Analysis of the Neologism 'Nüjie' in the Late Qing and Early Republic," Research on Qing History, no. 4 (2014); "The Mobility Experiences of Female Teachers and Students in the Late Qing and Early Republic with a Focus on Tianjin," Historical Review, no. 1 (2014); and "The Visual Representation of Women's Education in the Late Qing: A Case Study of Pictorials in Tianjin," Modern Chinese History Studies, no.1 (2013). The research for this article is jointly supported by the National Social Science Foundation for Young Scholars and by the Center 
for Cultural Construction, Collaboration, and Creativity and the Center for Study of Civilizations at Capital Normal University.

Emily BRUCE is a visiting assistant professor of history at the University of Minnesota-Morris, specializing in modern European history and the history of childhood. Her publications include "Reading German Girlhood: Louise Tilly and the Agency of Girls in European History," Social Science History 38, no. 1 (2014); and “'Each word shows how you love me': The social literacy practice of children's letter writing (1780-1860)," Pædagogica Historica 50, no. 3 (2014). The research for this article is jointly supported by the National Academy of Education/Spencer Foundation, the German Academic Exchange Service, and the University of Minnesota.

\author{
Glossary \\ Chen Hongmou 陈宏谋 \\ Wutong 梧桐 \\ Jiaonü yigui 教女遗规 \\ Lü Bicheng 吕碧城 \\ Lü Fengqi 吕凤岐 \\ Lü Huiru 吕惠如 \\ Lü Kunxiu 吕坤秀 \\ Lü Meisun 吕美荪 \\ nei/wai 内/外 \\ Qianzi wen 《千字文》 \\ Sanzijing 《三字经》 \\ Yan Shiyu 严士瑜
}

Bibliography

Albisetti, James, Joyce Goodman, and Rebecca Rogers, eds. Girls' Secondary Education in the Western World. New York: Palgrave Macmillan, 2010.

Bailey, Paul. Gender and Education in China: Gender Discourses and Women's Schooling in the Early Twentieth Century. London: Routledge, 2007.

Barkin, Kenneth. "Social Control and the Volksschule in Vormärz Prussia." Central European History 16, no. 1 (1983): 31-52.

Barth, Susanne. "Das Goldtöchterchen: Zur geschlechtsspezifischen Erziehung von Kleinen Mädchen im Kinderbuch um nach 1800" [The Little Golden Daughter: On the Gender-Specific Education of Little Girls in Childrens' Books around 1800]. Der Deutschunterricht: Beiträge zu 
Seiner Praxis und Wissenschaftlichen Grundlegung [German Instruction: Articles on Its Praxis and Academic Foundation] 42, no. 3 (1990): 61-75.

Bettina Brentano to Kunigunde Brentano, dated September 7, 1796, 101. In F. E. Mencken, Dein dich zärtlich liebender Sohn [Your Affectionate Loving Son]. Memmingen: Heimeran, 1965.

Chang Kang-I Sun 孙康宜. “Nüzi wucai bianshi de? 女子无才便是德?” [A Woman without Talent is Virtuous?]. In Wenxue jingdian de tiaozhan 文学经典的挑战 [Challenge to Literary Canons], edited by Chang Kang-I Sun, 268-291. Nanchang: Baihuazhou wenyi chubanshe, 2002.

Cong Xiaoping 丛小平. “Cong Muqin dao Guomin Jiaoshi: Qingmo minzu guojia jianshe yu gongli nüzi shifan jiaoyu 从母亲到国民教师——清末民族国家建设与公立女子师范教育” [From Mothers to Teachers of the Nation: State-Building and Normal Schools for Women during the Waning Years of the Qing Dynasty]. Qingshi yanjiu 清史研究 [The Qing History Journal], no. 1 (2003): 87-97.

Davis, Natalie Zemon. "'Women's History' in Transition: The European Case." Feminist Studies 3, no. 3/4 (1976): 83-103.

Dolz, Johannes Christian. Bildungsblätter oder Zeitung für die Jugend [Picture Pages, or A Magazine for Youth]. Leipzig: Georg Voß, 1806-1811.

Du Xueyuan 杜学元. Zhongguo nüzi jiaoyu tongshi 中国女子教育通史 [The Complete History of Women's Education in China]. Guizhou: Guizhou jiaoyu chubanshe, 1995.

Engelhardt, Karl. Neuer Kinderfreund [New Children's Friend]. Issue 10. Leipzig: Barth and Franz Haas, 1797.

Fong, Grace S. “Female Hands: Embroidery as a Knowledge Field in Women's Everyday Life in Late Imperial and Early Republican China." Late Imperial China 25, no.1 (June): 1-58.

Guang Tiefu 光铁夫. Anhui Mingyuan Shici Zhenglüe 安徽名媛诗词征略 [Poetry Collection of Elite Women in Anhui Province]. Hefei: Huangshan shushe, 1986. First published 1936 by Guang Tiefu.

Hasenfratz, Anna. Diary. 1841. File 1491.1. Deutsches Tagebucharchiv, Emmendingen.

Hermes, J. T. Sophiens Reise von Memel nach Sachsen [Sophie's Journey from Memel to Saxony]. Vol. 4. Leipzig: Junius, 1776. 
Ho, Clara Wing-Chung. "The Cultivation of Female Talent: Views on Women's Education in China during the Early and High Qing Periods." Journal of the Economic and Social History of the Orient 38, no.2 (1995): 191-223.

Hsiung, Ping-chen. A Tender Voyage: Children and Childhood in Late Imperial China. Stanford: Stanford University Press, 2005.

Hu, Ying. "Naming the First New Woman." Nan Nü: Men, Women, and Gender in China 3, no. 2 (2001): 196-231.

Jacobi, Juliane. "Girls' Secondary Education in Nineteenth- and Twentieth-Century Germany, Austria and Switzerland." Paper presented at the European Educational Research Conference, Goteborg, September 10, 2008.

Ko, Dorothy. Teachers of the Inner Chambers: Women and Culture in Seventeenth-Century China. Stanford: Stanford University Press, 1994.

Krahmer, Anna. Diary. 1830-1831. File 1677/II. Deutsches Tagebucharchiv, Emmendingen.

Liu Lijuan 刘丽娟. “Nüzi wucai bianshide kaoshu 女子无才便是德考述” [Historical Examination of a Woman without Talent is Virtuous]. Funü yanjiu luncong 妇女研究论丛 [Collection of Women's Studies], no. 5 (2009): 55-60.

Lü Fengqi 吕凤岐. Shizhushannong xingnian lu 石柱山农行年录 [Chronological Autobiography of Lü Fengqi]. Beijing: Beijing tushuguan chubanshe, 1999.

Lü Meisun 吕美称. “Chong zhi jingshi 重至京师” [Return to the Capital]. In Mianliyuan shi 葂 丽园诗 [Poetry Collection from the Mianli Garden], 5a-6a. Qingdao, 1931.

Lü Meisun 吕美称. “Meisun ziji sansheng yinguo 美䔉自记三生因果” [Meisun's Own Account of the Karma of Her Three Lives]. In Mianliyuan suibi 菟丽园随笔 [Random Notes from the Mianli Garden], 84-87. Qingdao: printed by author, 1941.

Lü Meisun 吕美称. “Paochu sha jie 庖厨杀戒” [Stop Killing in the Kitchen]. In Mianliyuan suibi 菟丽园随笔 [Random Notes from the Mianli Garden], 88. Qingdao: printed by author, 1941. Lü Meisun 吕美荪. “Xian waiwangmu Yan taifuren xian congmu Yu taifuren xiaoxing 先外王母 嚴夫人先從母余太夫人孝行” [The Filial Deeds of My Deceased Maternal Grandmother Madame Yan and My Deceased Aunt Madame Yu]. In Mianliyuan suibi 葂丽园随笔 
[Random Notes from the Mianli Garden], 15. Qingdao: printed by author, 1941.

Mann, Susan. "The Education of Daughters in the Mid-Ch'ing Period." In Education and Society in Late Imperial China, 1600-1900, edited by Benjamin A. Elman and Alexander Woodside, 1947. Berkeley: University of California Press, 1994.

Mann, Susan. "Learned Women in the Eighteenth Century." In Engendering China: Women, Culture, and the State, edited by Christina K. Gilmartin, Gail Hershatter, Lisa Rofel, and Tyrene White, 27-46. Cambridge, MA: Harvard University Press, 1994.

Mann, Susan. Precious Records: Women in China's Long Eighteenth Century. Stanford: Stanford University Press, 1997.

"Ein kleines Mädchen zeigt grossen Muth" ["A Little Girl Shows Great Courage"]. Neujahrsgeschenk für Kinder von einem Kinderfreunde [New Year's Gift for Children from a Children's Friend] vol. 2, 78. Frankfurt: J. J. Keßler, 1779.

Nösselt, Friedrich. Lehrbuch der Weltgeschichte für Töchterschulen [World History Reader for Girls' Schools]. Breslau: Mar, 1827.

Pomata, Gianna. “History, Particular and Universal: On Reading Some Recent Women's History Textbooks." Feminist Studies 19, no. 1 (1993): 7-50.

Qin Fang 秦方. “Wanqing cainü de chengzhang licheng: Yi Anhui Jingde Lüshi zimei wei zhongxin 晚清才女的成长历程: 以安徽旌德吕氏姊妹为中心” [The Construction of Talented Women's Girlhood in the Late Qing Dynasty: A Case Study of the Lü Sisters of Jingde, Anhui]. Jindai zhongguo funü shi yanjiu 近代中国妇女史研究 [Research on Modern Chinese Women's History], no. 19 (2010): 259-294.

Reinhardt, J. G. Der Mädchenspiegel [The Girl's Mirror]. Halle: Johann Jacob Gebauer, 1794.

Schulz, M. Christian. Mungo Park's Reise in Afrika für die Jugend bearbeitet [Mungo Park's Travels in Africa Presented for Youth ]. Berlin: Schüppelschen Buchhandlung, 1805.

Seybold, Marie. Diary. 1830-1831. File Q 3/48 Box 3. Familiennachlass Schmidt. Hauptstaatsarchiv Stuttgart.

Smith, Joanna F. Handlin. "Liberating Animals in Ming-Qing China: Buddhist Inspiration and Elite Imagination." Journal of Asian Studies 58, no. 1 (1999): 51-84.

Vincent, David. The Rise of Mass Literacy. Cambridge: Polity Press, 2000. 
Wu, Pei-yi. "Education of Children in the Sung." In Neo-Confucian Education: The Formative Age, edited by William Theodore de Bary and John W. Chaffee, 307-324. Berkeley: University of California Press, 1989.

Xia Xiaohong 夏晓虹. “Zhongxi hebi de jiaoyu lixiang: Shanghai 'zhongguo nüxuetang' kaoshu 中 西合璧的教育理想——上海“中国女学堂”考述” [The Educational Ideal of Combining the Chinese and the Western: The Verification and Analysis of Shanghai 'China Girls' School']. In Wanqing nüxing yu jindai Zhongguo 晚清女性与近代中国 [Late-Qing Women and Modern China] , 3-37. Beijing: Beijing daxue chubanshe, 2004.

Yi Ruolan 衣若兰. Shixue yu xingbie: Mingshi lienüzhuan yu mingdai nüxingshi zhi jiangou 史学 与性别：明史列女传与明代女性史之建构 [History and Gender: The Biographies of Virtuous Women in History of the Ming Dynasty and the Construction of Women's History in the Ming Dynasty]. Taiyuan: Shanxi jiaoyu chubanshe, 2012. 